Original Research Article

\title{
A prospective observational study and survival pattern of organo phosphorous poisoning patients with intensive care treatment in a tertiary care hospital
}

\author{
Kanamala Arun Chand Roby1*, B. Srinivas², B. Sandeep ${ }^{2}$, S. Nikhil Reddy², M. Ajay Yadav $^{2}$, \\ Kudipudi Harinadha Baba $^{3}$
}

\author{
${ }^{1}$ Department of Pharmacy \\ Practice, Narayana Pharmacy \\ College, Nellore, Andhra \\ Pradesh, India \\ ${ }^{2}$ Student, SCIPS, Karimnagar, \\ Telangana, India \\ ${ }^{3}$ Department of Pharmaceutical \\ Analysis, Shivani College of \\ Pharmacy, Srikakulam, Andhra \\ Pradesh, India
}

Received: 03 April 2018

Revised: 16 June 2018

Accepted: 26 June 2018

\section{*Correspondence to:}

Dr. Kanamala Arun Chand

Roby,

Email: arunchandroby@ gmail.com

Copyright: (C) the author(s), publisher and licensee Medip Academy. This is an openaccess article distributed under the terms of the Creative Commons Attribution NonCommercial License, which permits unrestricted noncommercial use, distribution, and reproduction in any medium, provided the original work is properly cited.

\begin{abstract}
Background: Organophosphate poisoning is poisoning due to organophosphates (OP's), used in insecticides, medications and nerve agents. It occurs mostly during suicide attempts in the farming areas, developing world and less by accident. The study is to evaluate the drugs used, respiratory conditions, complications occurred during course of treatment.

Methods: This was a prospective observational study conducted for 9 months in a tertiary care hospital. The study was conducted in a 500 bedded tertiary care hospital in an intensive care unit. The study was conducted for nine months (September 2016 - May 2017).

Results: A total of 234 patients who had consumed OPP with known and unknown agents were admitted in the emergency department. Out of which 180 males and 54 females.

Conclusions: This study concluded that the patients consumed poison is mainly due to mental disturbances and financial problems. The stress and burden on the life will shows the effect after consumption, the maximum people suffer with respiratory problems due to poison consumption. If the government should take the measures to avoid consumption of poison and availability of poison to the public may overcome the complications and reduce the deaths due to poison.
\end{abstract}

Keywords: Anticholinergics, Antidote, Bronchospasm, Family disharmony, Op poisoning, Tracheostomy

\section{INTRODUCTION}

Poisoning is one of the major causes of the hospitalization through the emergency department and is a major public health problem. ${ }^{1}$ A case of poison is also defined as the overdose of drugs. Since 1945 some 15000 individual compounds and more than 35000 different formulations have come into use as pesticide. ${ }^{2,3}$ The wide spread uses of agents are particularly the organophosphates; physicians have been called on to diagnose and manage a large number of poisoning cases. ${ }^{4,5}$ The poison can be consumed as a method of assassination, murdered, suicide and execution. ${ }^{6}$ Poison lethal effect can be combined with its allegedly magical effects organo phosphorous compound is an important medical emergency in which if early treatment is not received mortality is high. ${ }^{7}$ The leading cause of death is due to respiratory failure its results from combination of respiratory muscle weakness, central 
respiratory depression, increased bronchial secretion, bronchospasm, pulmonary edema. Hence the study was carried with the aim to identify factors related to outcomes and to suggest strategy to reduce associated mortality and morbidity. 8,9

\section{METHODS}

The study was prospective observational study conducted in tertiary care hospital. The study was done in the patients of intensive care unit and acute medical care unit.

The study was done by collecting information using patient case sheets, based on the data a questionnaire is prepared. Nearly data of 234 patient were collected which include case history, demographic details, reason of consumption, part medical history, laboratory values, and drugs prescribed with their dosage and frequency of poison consumption were collected. ${ }^{10}$ All patients as age below 18 to 60 who consumed poison are to be taken for study. The study was conducted for (September 2016 - May 2017).

\section{Inclusion criteria}

The patient who consumed poison who undergone ventilation patient age below 18 to 60 . Patient of both sexes

\section{Exclusion criteria}

- Who are not willing to give information.

- Pregnancy and lactating mother.

- Infectious diseases (AIDS, TB)

\section{Study material}

\section{Patient consent form}

Consent was collected by using self designed patient consent form and consent was made into three languages English, Telugu, Hindi. The Study was approved by Institutional Ethical committee of Narayana Medical College and Hospital, Nellore.

\section{Data analysis}

A data was analyzed by demographic details reason for admission and frequency as stay in ICU. Prescribe antidotes, severity in conditions. Complications during treatment and survival rate, laboratory values drugs prescribed was analyzed by statistical software's the data was analyzed by using MS - excel and result was given by percentage. ${ }^{11,12}$

\section{RESULTS}

The demographic details of the patients shows that maximum patients were male and minimum females, and the age group mostly consumed poison were 18-24 with marital status of married were maximum, with educational level of mostly secondary and nutritional status of poor. ${ }^{13-17}$

Table 1: The demographic details of the patients including age sex, marital status, educational level, nutritional status.

\begin{tabular}{|llll|}
\hline \multicolumn{2}{|l}{ Demographics } & $\begin{array}{l}\text { No. of } \\
\text { patients }\end{array}$ & $\begin{array}{l}\text { Percentage } \\
(\%)\end{array}$ \\
\hline \multirow{4}{*}{ Age } & $18-24$ & 72 & 30 \\
\cline { 2 - 4 } & $25-35$ & 36 & 15 \\
\cline { 2 - 4 } & $36-45$ & 27 & 11 \\
\hline \multirow{2}{*}{ Sex } & $46-52$ & 72 & 30 \\
\hline Marital & $52-60$ & 27 & 42 \\
status & Male & 127 & 54 \\
\hline \multirow{2}{*}{$\begin{array}{l}\text { Educational } \\
\text { level }\end{array}$} & Female & 107 & 46 \\
\cline { 2 - 4 } & Married & 135 & 58 \\
\hline \multirow{3}{*}{$\begin{array}{l}\text { Nutritional } \\
\text { status }\end{array}$} & Secondary & 126 & 54 \\
\cline { 2 - 4 } & Tertiary & 36 & 15 \\
\cline { 2 - 4 } & Poor & 126 & 54 \\
\cline { 2 - 4 } & Average & 72 & 31 \\
\hline
\end{tabular}

Table 2: The reason for consumption, the maximum consumption is due to mental disorder and family disharmony.

\begin{tabular}{|lll|}
\hline Reasons & $\begin{array}{l}\text { No. of } \\
\text { patients }\end{array}$ & $\begin{array}{l}\text { Percentage } \\
(\%)\end{array}$ \\
\hline Family disharmony & 36 & 15 \\
\hline Mental disorder & 63 & 27 \\
\hline Conflict in work area & 18 & 07 \\
\hline Financial problem & 36 & 15 \\
\hline For tradition medicine & 27 & 12 \\
\hline Drug abuse & 09 & 04 \\
\hline Unsuccessful love failure & 27 & 12 \\
\hline $\begin{array}{l}\text { Domestic violence (pregna } \\
\text { ncy after raped) }\end{array}$ & 09 & 04 \\
\hline Marital disharmony & 09 & 04 \\
\hline
\end{tabular}

Table 3: How much milliliters of poison consumed by the patients the maximum amount consumed by patients is below $50 \mathrm{ml}$.

\begin{tabular}{|lcc|}
\hline Amount consumed & No. of patients & $\begin{array}{l}\text { Percentage } \\
(\%)\end{array}$ \\
\hline Below 50ml & 72 & 31 \\
\hline $50-100 \mathrm{ml}$ & 63 & 27 \\
\hline $100-150 \mathrm{ml}$ & 45 & 19 \\
\hline Above $150 \mathrm{ml}$ & 54 & 23 \\
\hline
\end{tabular}

The reason for consumption of poison was mostly mental disorder (Psychological stress) and financial problems. 
The quantity of poison consumed by the patients was mostly $50 \mathrm{ml}$ and least of $100-150 \mathrm{ml}$.

Table 4: The number of poison patients outcomes during and after the treatment.

\begin{tabular}{|lll|}
\hline Outmost outcome & $\begin{array}{l}\text { No. of } \\
\text { patients }\end{array}$ & $\begin{array}{l}\text { Percentage } \\
(\%)\end{array}$ \\
\hline Recovered & 181 & 77 \\
\hline Death & 27 & 12 \\
\hline Absconded & 07 & 03 \\
\hline Discharge at request & 09 & 04 \\
\hline Referred to higher hospitals & 08 & 04 \\
\hline
\end{tabular}

The maximum number of patients recovered after the consumption of poison and least referred to higher centers and some of the patients were died during treatment.

Table 5: The number of people suffered with respiratory distress or bronco-constriction and undergone for ventilation.

\begin{tabular}{|lll|}
\hline Treatment & No. of patients & Percentage (\%) \\
\hline $\begin{array}{l}\text { Abnormal } \\
\text { ventilation }\end{array}$ & 180 & 77 \\
\hline Tracheostomy & 54 & 23 \\
\hline
\end{tabular}

The maximum number of patients is suffered with respiratory distress and broncho- constriction and undergone normal ventilation and tracheostomy.

Table 6: The signs and symptoms of patients consumed OP poisoning and most of the patients experienced bradycardia.

\begin{tabular}{|lll|}
\hline Signs and symptoms & $\begin{array}{l}\text { No. of } \\
\text { patients }\end{array}$ & $\begin{array}{l}\text { Percentage } \\
(\%)\end{array}$ \\
\hline Bradycardia & 207 & 88 \\
\hline Hypotension & 180 & 76 \\
\hline Bronchospasm & 162 & 69 \\
\hline $\begin{array}{l}\text { Severe respiratory } \\
\text { distress }\end{array}$ & 198 & 85 \\
\hline Hyper salivation & 90 & 38 \\
\hline Abdominal pain & 72 & 31 \\
\hline $\begin{array}{l}\text { Fecal incontinence } \\
\text { (constipation) }\end{array}$ & 207 & 88 \\
\hline Incontinence & 124 & 53 \\
\hline Blurred vision & 36 & 15 \\
\hline Suture & 09 & 04 \\
\hline Anxiety & 72 & 31 \\
\hline Coma & 05 (recovered & 02 \\
\hline Confusion & 108 & 46 \\
\hline Ataxia & 117 & 50 \\
\hline
\end{tabular}

The signs and symptoms of the poison consumed patients were mostly bradycardia, respiratory distress, fecal incontinence and least were abdominal pain. Procedure followed in the emergency ward after entering into the hospital.

Table 7: The antidotes given to the patients for their survival and for the outcomes.

\begin{tabular}{|lll|}
\hline Antidote & No. of patients & Percentage (\%) \\
\hline Atropine & 234 & 100 \\
\hline Paralidoxime & 234 & 100 \\
\hline Glycopyrrolate & 216 & 92.30 \\
\hline Diazepam & 234 & 100 \\
\hline
\end{tabular}

The antidotes given to patients for their survival are mostly atropine, paralidoxime, diazepam for sedation and Glycopyrrolate for the recovery.

Table: 8: The procedures followed during hospital admission.

\begin{tabular}{|lll|}
\hline Procedure & $\begin{array}{l}\text { No. of } \\
\text { patients }\end{array}$ & $\begin{array}{l}\text { Percentage } \\
(\%)\end{array}$ \\
\hline Stomach lavage & 234 & 100 \\
\hline $\begin{array}{l}\text { Irrigation of eyes with } \\
\text { isotonic solution }\end{array}$ & 90 & 38.46 \\
\hline Airway control & 171 & 73.07 \\
\hline ECG & 234 & 100 \\
\hline IV magnesium sulfate & 162 & 69.23 \\
\hline
\end{tabular}

Table 9: The classes of antidotes given for the OP poisoning patients to overcome the symptoms and conditions.

\begin{tabular}{|lll|}
\hline $\begin{array}{l}\text { Classes of antidotes } \\
\text { given }\end{array}$ & $\begin{array}{l}\text { No. of } \\
\text { prescriptions }\end{array}$ & $\begin{array}{l}\text { Percentage } \\
(\%)\end{array}$ \\
\hline $\begin{array}{l}\text { Anticholinergic } \\
\text { (Atropine) }\end{array}$ & 234 & 100 \\
\hline $\begin{array}{l}\text { Antimuscarnic } \\
\text { (Glycopyrrolate) }\end{array}$ & 198 & 84.61 \\
\hline $\begin{array}{l}\text { Acetylcholinestarase } \\
\text { inhibitors (PAM) }\end{array}$ & 234 & 100 \\
\hline $\begin{array}{l}\text { Benzodiazepam } \\
\text { (Diazepam) }\end{array}$ & 216 & 92.3 \\
\hline
\end{tabular}

Table 10: The other treatment given to the patients to overcome the complications and infections.

\begin{tabular}{|lll|}
\hline Medications & $\begin{array}{l}\text { No. of } \\
\text { patients }\end{array}$ & $\begin{array}{l}\text { Percentage } \\
(\%)\end{array}$ \\
\hline Lasix (Furosemide) & 98 & 41.88 \\
\hline Avil (pheniramine malate) & 117 & 50.00 \\
\hline Ceftrioxone-1gm & 234 & 100 \\
\hline PPI's/H2RA - Pantoprazole & 234 & 100 \\
\hline Hydrocortisone & 198 & 81.19 \\
\hline Amoxicillin + Potassium & 99 & 42.30 \\
\hline Ranitidine & 36 & 15.38 \\
\hline
\end{tabular}

The classes of drugs given for the OP poison were Anticholinergics, Acetylcholinestarase inhibitors, 
benzodiazepines and antimuscarnic are the classes of drugs for poison. The treatment given to patients to overcome the complications like ICU infections, gastric irritation and the drugs given were mostly Furosemide, Pantoprazole, cefatriaxone.

Table 11: The investigations performed to the patients to check the abnormalities occurred due to poisoning.

\begin{tabular}{|ll|l|}
\hline $\begin{array}{l}\text { Lab tests } \\
\text { performed }\end{array}$ & $\begin{array}{l}\text { No. of patients } \\
\text { raised }\end{array}$ & $\begin{array}{l}\text { Percentage } \\
(\%)\end{array}$ \\
\hline CBP - Hb & 63 & 26.92 \\
\hline ESR & 36 & 15.38 \\
\hline WBC & 18 & 07.79 \\
\hline PC & 27 & 11.53 \\
\hline HCT & 27 & 11.53 \\
\hline MCH & 09 & 03.84 \\
\hline MHCH & 36 & 15.38 \\
\hline PCV & 09 & 03.58 \\
\hline
\end{tabular}

The investigations performed to the patients to check the abnormalities occurred due to poison and find that only some of the parameters are raised lie $\mathrm{Hb}, \mathrm{ESR}, \mathrm{PC}, \mathrm{HCt}$.

Table 12: The estimation of serum cholinesterase to check the therapy is either effective or not.

\begin{tabular}{|lll|}
\hline $\begin{array}{l}\text { Serum } \\
\text { cholinesterase }\end{array}$ & $\begin{array}{l}\text { No. of } \\
\text { patients }\end{array}$ & $\begin{array}{l}\text { Percentage } \\
(\%)\end{array}$ \\
\hline Performed & 180 & 76.92 \\
\hline Not performed & 54 & 23.07 \\
\hline
\end{tabular}

The serum cholinesterase test was performed to check the effectiveness of therapy and performed only in 180 out of 234 patients.

Table 13: The patients with the changes in the color of the urine.

\begin{tabular}{|lll|}
\hline $\begin{array}{l}\text { Discoloration of } \\
\text { urine }\end{array}$ & $\begin{array}{l}\text { No of } \\
\text { patients }\end{array}$ & Percentage (\%) \\
\hline Normal & 72 & 30.07 \\
\hline Yellow color & 36 & 15.38 \\
\hline Chocolate brown & 90 & 38.46 \\
\hline Red & 36 & 15.38 \\
\hline
\end{tabular}

The change in discoloration of urine due to drugs and poison and the color observed was mostly chocolate brown, yellow color, and red.

According to the summary the number of patients consumed poison in different months was analyzed and the maximum consumption was observed in October, august, march and least in June.

The clarity on poison consumption for the patients admitted in the hospital are mostly poison unknown, patients brought the container, patients without container and known poison.

Table 14: The no of patients consumed poison according to month wise.

\begin{tabular}{|ll|l|}
\hline Month & $\begin{array}{l}\text { Month wise } \\
\text { consumption }\end{array}$ & $\begin{array}{l}\text { Percentage } \\
(\%)\end{array}$ \\
\hline February & 25 & 10.68 \\
\hline March & 30 & 12.82 \\
\hline April & 20 & 08.54 \\
\hline May & 25 & 10.68 \\
\hline June & 19 & 08.11 \\
\hline July & 25 & 10.68 \\
\hline August & 31 & 13.24 \\
\hline September & 25 & 10.68 \\
\hline October & 34 & 14.52 \\
\hline
\end{tabular}

Table 15: Indicates that the patients admitted with known poison or unknown poison to treat or to make the treatment easy.

\begin{tabular}{|lll|}
\hline Clarity on poison & $\begin{array}{l}\text { No of } \\
\text { patients }\end{array}$ & $\begin{array}{l}\text { Percentage } \\
(\%)\end{array}$ \\
\hline Poison known & 108 & 46.15 \\
\hline Poison unknown & 126 & 53.84 \\
\hline Patient bring the containers & 126 & 53.84 \\
\hline Patients without containers & 108 & 46.15 \\
\hline Due to smell & Nil & 0 \\
\hline
\end{tabular}

\section{DISCUSSION}

Out of 234 patients who are admitted in the hospital with poison consumption are of age group 18-60 (100\%) and both sexes $(100 \%)$ with secondary level education and nutritional status of mostly poor. ${ }^{1,2,11}$ The reason for admission in the hospital is due to mental disorder (depression) (27\%) and family disharmony (15\%) and financial problems $(15 \%)$. The people consumed poison of less than $50 \mathrm{ml}$ is more $(31 \%)$ and $50-100 \mathrm{ml}$ is $(27 \%) .{ }^{13}$ The people under abnormal ventilation is required for 180 (77\%) and tracheotomy for 54 (23\%) patients. Maximum all the signs and symptoms are observed and mostly bradycardia (88\%) hypotension $(76 \%)$ and bronchospasm $(69 \%)$ are commonly observed. ${ }^{18,19}$ All the patients are treated with antidotes like atropine (100\%) and paralidoxime $(100 \%)$ and sedatives like diazepam is given $(100 \%)$ and all the normal procedures were followed, and the maximum classes of antidotes are Anticholinergics. Normal medications like antibiotics and other are prescribed in hospital stay. Laboratory tests performed to check the ranges in the patients. ${ }^{20,21}$ Estimation of serum cholinesterase was performed in $180(77 \%)$ patients to know the condition of the patient. ${ }^{22}$ Discoloration of urine was observed maximum in chocolate brown (90\%) and maximum cases was observed in March and August and the people consumed poison also have clarity on poison is $100 \%$ with all the readings are tabulated as above..$^{23,24}$ 


\section{CONCLUSION}

From this study, concluded that the patients consumed poison is mainly due to mental disturbances and financial problems. The stress and burden on the life will shows the effect after consumption, the maximum people suffer with respiratory problems due to poison consumption. If the government should take the measures to avoid consumption of poison and availability of poison to the public may overcome the complications and reduce the deaths due to poison consumption. The easy availability may lead the person to take decisions without knowledge. As authors are the clinical pharmacists we should create awareness. In the areas about their lifestyles and causes after consumption may avoid poison consumption. So many researches want to do to show complications due to poisons.

\section{ACKNOWLEDGEMENTS}

All thanks and praises to God Almighty for his countless, abundant and never-ending blessings in completing this work. It is a proud privileged honour for authors to express their hatful thanks and gratefulness to all the persons who backed directly or indirectly through out of this research work as magnitude. Most importantly authors are thankful to patients and health care professionals.

Funding: No funding sources

Conflict of interest: None declared

Ethical approval: The study was approved by the Institutional Ethics Committee of Narayana Medical College and Hospital, Nellore, India

\section{REFERENCES}

1. Eddleston M, Szinicz L, Eyer P, Buckley N. Oximes in acute organophosphorus pesticide poisoning: a systematic review of clinical trials. QJM. 2002 May 1;95(5):275-83.

2. Buckley NA, Eddleston M, Szinicz L. Oximes for acute organophosphate pesticide poisoning. In: The Cochrane Library, Issue 4, 2014. Chichester, UK: John Wiley and Sons, Ltd. Search date; 2009.

3. Vale JA. Toxicokinetic and toxicodynamic aspects of organophosphorus (OP) insecticide poisoning. Toxicol Lett. 1998;102-103:649-652.

4. Lotti M. Clinical toxicology of anticholinesterase agents in humans. In: Krieger RI, Doull J, eds. Handbook of pesticide toxicology. San Diego: Academic Press; 2001:1043-1085.

5. Karalliedde L, Baker D, Marrs TC. Organophosphateinduced intermediate syndrome: aetiology and relationships with myopathy. Toxicol Rev. 2006;25:114.

6. Eddleston M, Mohamed F, Davies JO, Eyer P, Worek F, Sheriff MR, et al. Respiratory failure in acute organophosphorus pesticide self-poisoning. J Ass of Physici. 2006 Aug 1;99(8):513-22.
7. Eyer P. Neuropsychopathological changes by organophosphorus compounds - a review. Hum Exp Toxicol. 1995;14:857-64.

8. Delgado E, McConnell R, Miranda J, Keifer M, Lundberg I, Partanen T, et al. Central nervous system effects of acute organophosphate poisoning in a twoyear follow-up. Scand J Wor, Enviro Hea. 2004 Oct 1:362-70.

9. Wadia RS, Bhirud RH, Gulavani AV. Neurological manifestations of three organophosphate poisons. Indian J Med Res.1977;66:460-8.

10. Eddleston M, Eyer P, Worek F, Mohamed F, Senarathna L, von Meyer L, et al. Differences between organophosphorus insecticides in human selfpoisoning: a prospective cohort study. The Lancet. 2005 Oct 22;366(9495):1452-9.

11. Karalliedde L, Eddleston M, Murray V. The global picture of organophosphate insecticide poisoning. In Organophosphates and health; 2001:431-471.

12. Eddleston M. Patterns and problems of deliberate selfpoisoning in the developing world. QJM. 2000;93:715-31.

13. Roberts DM, Karunarathna A, Buckley NA, Manuweera G, Sheriff MH, Eddleston M. Influence of pesticide regulation on acute poisoning deaths in Sri Lanka. Bull World Health Organ. 2003;81:789-98.

14. Wesseling C, McConnell R, Partanen T, Hogstedt C. Agricultural pesticide use in developing countries: health effects and research needs. Int J Hea Servic. 1997 Apr;27(2):273-308.

15. Eyer P. The role of oximes in the management of organophosphorus pesticide poisoning. Toxicol Rev. 2003;22:165-90.

16. Cherian MA, Roshini C, Visalakshi J, Jeyaseelan L, Cherian AM. Biochemical and clinical profile after organophosphorus poisoning- a placebo-controlled trial using pralidoxime. JAPI. 2005 May;53:427-31.

17. Eddleston M, Eyer P, Worek F, Juszczak E, Alder N, Mohamed F, et al. Pralidoxime in acute organophosphorus insecticide poisoning- a randomised controlled trial. PLoS medicine. 2009 Jun 30;6(6):e1000104.

18. Cherian AM, Peter JV, Samuel J, Jaydevan R, Peter S, Joel S, et al. Effectiveness of P2AM (PAMpralidoxime) in the treatment of organophosphorus poisoning. A randomised, double-blind, placebocontrolled trial. J Assoc Physicians India. 1997;45:224.

19. Johnson MK, Jacobsen D, Meredith TJ, Eyer P, Heath AJ, Ligtenstein DA, et al. Evaluation of antidotes for poisoning by organophosphorus pesticides. Emergency Medicine. 2000 Mar 6;12(1):22-37.

20. International Programme on Chemical Safety. Poisons Information Monograph G001. Organophosphorus pesticides. World Health Organization, Geneva, 1989; updated 1999. Available at: http://www.inchem.org/documents/pims/chemical/pi mg001.htm (last accessed 26 August 2015).

21. Worek F, Bäcker M, Thiermann H, Szinicz L, Mast U, Klimmek R, et al. Reappraisal of indications and 
limitations of oxime therapy in organophosphate poisoning. Human Experim Toxicol. 1997 Aug;16(8):466-72.

22. Worek F, Eyer P, Kiderlen D, Thiermann H, Szinicz L. Effect of human plasma on the reactivation of sarininhibited human erythrocyte acetylcholinesterase. Archives of toxicology. 2000 Mar 1;74(1):21-6.

23. Bismuth C, Inns RH, Marrs TC. Efficacy, toxicity and clinical uses of oximes in anticholinesterase poisoning. In: Ballantyne B, Marrs TC, eds. Clinical and experimental toxicology of organophosphates and carbamates. Oxford: Butterworth Heinemann; 1992:555-577
24. Eddleston M, Street JM, Self I, Thompson A, King T, Williams N, et al. A role for solvents in the toxicity of agricultural organophosphorus pesticides. Toxicol. 2012 Apr 11;294(2-3):94-103.

Cite this article as: Roby KAC, Srinivas B, Sandeep B, Reddy SN, Yadav MA, Kudipudi HB. A prospective observational study and survival pattern of organo phosphorous poisoning patients with intensive care treatment in a tertiary care hospital. Int J Basic Clin Pharmacol 2018;7:1889-94. 